\title{
The assessment of perceived service quality dimensions of hotel industry in Bangladesh
}

\author{
Md. Alauddin, Syed Md. Hasib Ahsan, Md. Aktar Kamal, Mohammad Manjur Alam, , Azizul Hassan*
}

\author{
Keywords: \\ Service Quality (SQ), \\ Customer Expectation, \\ Customer Perception, \\ SERVQUAL model, \\ Hotel, \\ Bangladesh (BNG).
}

\author{
Article History: \\ Submitted: 07.04.2020 \\ Accepted: 01.09.2020
}

\section{ABSTRACT}

This research aims to identify the gaps between customer expectation and customer perception on service quality of the hotel industry in Bangladesh based on five dimensions of service quality, namely "reliability, responsiveness, assurance, empathy, and tangibles". This study surveyed 300 respondents from different tourist spots of Cox's Bazar and Saint Martin based on self-administered "modified SERVQUAL questionnaire". Data were analysed using "mean, reliability test, independent sample ttest and one -way ANOVA test and single analysis of variance (ANOVA)" via SPSS version 22. The study adopts a different statistical test based on the primary data. Results indicated that tourists' perceptions failed to light their demand on the service quality of hotel sectors in Bangladesh. Results also show that tourists' expectations and perceptions in the case of tangibles and empathy dimensions are not significant in an independent sample t-test based on Gender and nationality respectively. However, in one-way ANOVA t-tests based on age, educational background and occupation; there is a significant difference between customer expectations and perception in the case of only two dimensions, which is reliability and empathy. The outcomes are anticipated to provide necessary guidelines to the service entrepreneurs for boosting the customer satisfaction level by identifying the gaps of the hotel industry in Bangladesh.

Doi: https://doi.org/10.31822/jomat.715717

\section{Introduction}

Service quality (SQ) becomes an important issue in today's business sectors. Service entrepreneurs are emphasizing heavily on this topic to attract their existing and potential customers. Without providing better service, achieving customer loyalty will be difficult (Hassan et al., 2019). Considering the issues, this study has been underscored to analyse the critical fact of service quality in the academic and corporate arena. Though there is a lot of research, it has been conducted on SQ but quality-related issues have not found more within the service settings context especially held in Bangladesh. Modern business is now entirely depending on better service, so service quality has become an integral parting of the market. It is considered for attracting and satisfying clients. Today's service entrepreneurs are focusing now on how to deliver efficient service to retain their customers. Researchers are trying for a long time how to apply theory and methods in the service industry which we tin say hospitality industry. Bojanic and Rosen (1994), for instance, tested the "SERVQUAL framework" in the restaurant industry, whilst the same model was applied by Saleh and Ryan (1991) in the lodging industry. Some other researchers like Knutson and colleagues have also tried to establish a scale for

*Corresponding Author Md. Alauddin: PhD Candidate, Department of Marketing, City University of Hong Kong, Kowloon, Hong Kong \& Assistant Professor (Study Leave, Department of Business Administration, International Islamic University Chittagong, Bangladesh; Email address: malauddin2-c@my.cityu.edu.hk; Orcid id: 0000-0002-8350-7557

Syed Md. Hasib Ahsan: $\quad$ Assistant Professor, Department of Business Administration, International Islamic University Chittagong, Bangladesh; Email address:hasib27ahsan@gmail.com, Orcid id:0000-0002-4286-5032

Md. Aktar Kamal: $\quad$ MSc in International Tourism and Convention Management, The Hong Kong Polytechnic University, Hong Kong \& Assistant Professor, Department of Management Studies, Faculty of Business Studies (FBS), Bangladesh University of Professionals, Bangladesh; Email address: aktar.kamal@bup.edu.bd, Orcid id: 0000-0002-0096-3902

\begin{aligned} \hline $\begin{array}{r}\text { Mohammad Manjur } \\ \text { Alam: }\end{array} & \begin{array}{l}\text { Assistant Professor, Department of Computer Science and Engineering, International Islamic University Chittagong, } \\ \text { Bangladesh; Email address: manjuralam44@ yahoo.com, Orcid id: 0000-0001-8619-4464 }\end{array} \\$\hline Azizul Hassan: & $\begin{array}{l}\text { Tourism Consultants Network, the Tourism Society, UK; Email address: azizulhassan00@ gmail.com; Orcid id: 0000- } \\ \text { 0002-0636-963X }\end{array}\end{aligned}$


identifying the quality of lodging facilities (Knutson et al., 1992; Patton et al., 1994). Similarly, Getty and Thompson (1994) suggested a scale to quantify for the above sectors. Along with these research efforts, Barsky (1992) and Barsky and Labagh (1992) have attempted to present a customer satisfaction research framework, called "the expectancy-disconfirmation model", into both the hotel and restaurant industry. This research attempts to identify the gaps between customer expectation and customer perception on SQ of the hotel industry in Bangladesh based on five dimensions, namely-"reliability, responsiveness, assurance, empathy and tangibles" where we have applied SERVQUAL model. Many researchers from Bangladesh and abroad used this model for different purposes. Some of them have measured the level of customer satisfaction, some of them have worked on identifying the relationship between SQ and customer satisfaction. In such context, this research especially concentrated on gap analysis. This is also the original value of this research.

\section{Literature Review}

The battle for customer satisfaction (CS) through SQ in the hospitality industry has been increased remarkably. This is happening because of customer retention through satisfaction and service quality became important issue in the hospitality industry. Nowadays, most of the lodging firms applied corporate-wide quality development programs to improve customer retention and service offering (Jeong and Oh, 1998). The researcher argued that customer loyalty and satisfaction level is significantly affected by SQ (Zaibaf et al., 2013; Donnelly et al., 2006). Quality service facilitates increased profitability, improved performance, and decreased cost which ultimately satisfies the customer and leads to positive favorable word of mouth (Seth et al., 2005; Buttle, 1995). Marketers started to formulate and consider tactics to measure and control service quality. Tourism and hospitality service providers consider these issues important due to the following justifications: tourism and hotel service, as intangible in nature, not possible to assess before consumption (Lewis and Chambers, 2000); many tourism and hospitality service offerings are considered as more risk consumptions (Lewis and Chambers, 2000); tourism and hospitality offerings are both perishable and seasonal, increasing pressure levels for service providers (Rao and Singhapakdi, 1997); the tourism and hospitality sector is highly competitive, signifying that the upper-level quality services can deliver vital competitive advantages for them who adopt early (Zaibaf et al., 2013).

Quality means that consumers search for an offer that will meet their demand (Solomon, 2009). Quality is defined as the characteristics and totality of features of a service or services that bear on its ability for satisfying stated or implied needs (Kotler et al., 2002). Recently, many researchers have worked on SQ in the hotel industry (e.g. Juwaheer, 2004; Ekinci et al., 2003; Tsang and Qu, 2000; Mei et al., 1999). The effects of these papers have created several influences in these sectors. At the same time, these studies have proved that no hotel tin do better business without ensuring quality and resort hotels, motels, airport hotels, and convention hotels, should be established for attracting the local and foreign tourists that hotels must have different distinguishing features. Studies observed that some of the important dimensions were dissimilar from the five characteristics in a hotel setting, designated by the original SERVQUAL researchers. Akan (1995) prepared a "questionnaire adapted from the SERVQUAL instrument and investigated the application of the SERVQUAL instrument in an international environment". Mei, Dean and White (1999) examined the dimensions of the hotel industry for Australia. They used the "SERVQUAL instrument as a foundation and developed a new scale called Holserv scale, a new instrument to measure service quality in the hotel industry". Saleh and Ryan (1992) shepherded a study on the hotel industry and identified five dimensions of SQ. However, they were established "conviviality, tangibles, reassurance, avoid sarcasm and empathy", and they deviated from those in the SERVQUAL instrument. Oberoi and Hales (1990) established a scale to measure SQ in a conference on hotels in the UK. According to this study, the perception of service quality was two classes, and consisted of "tangibles and intangibles". Webster and Hung (1994) developed a questionnaire for measuring SQ in the hotel industry based on the SERVQUAL instrument.

\section{Measuring Service Quality Gaps}

Lewis and Booms (1983) have compared the term between perception and expectation. From the perspective of business, service quality is considered as an added value of customer service. Service is defined as "any intangible act or performance that one party offers to another that does not result in the ownership of anything" (Kotler and Keller, 2009, p.789). Quality of service is the prime element, which we can distinguish 
service products. Tourists' perceptions differ from person to person due to different values and beliefs for measuring service quality. (Edvardsson, 1996). By measuring the differences between expectations and perceptions of perceived quality, it will be possible to find the level of satisfaction (Mazumder and Hasan, 2014). This idea was recommended by Parasuraman, Zenithal, and Berry (1985), which applied the "expectancy- disconfirmation theory".

- The five key differences that affect customer evaluations of service quality can be:

- The first was the gap between customer expectations and management's perceptions of those expectations.

- The second was the gap between management's perception of what the customer wants and specifications of service quality.

- The third was the gap between service quality specifications and the delivery of the service.

- The fourth was the gap between service delivery and what the company promises to the customer through external communication.

- The fifth was the gap between customers' service expectations and their perceptions of service performance.

Later to the gap model, Parasuraman, Zeithaml and Berry (1985) designed the "SERVQUAL instrument to identify and measure the gaps between customers' expectations and perceptions of service quality". Parasuraman, Zeithaml and Berry (1985) defined "service quality in 10 major dimensions that consumers use in forming expectations about, and perceptions of, services and in later research". Parasuraman, Zeithaml and Berry (1988) revised and defined the service quality into five dimensions - reliability, responsiveness, assurance, empathy, and tangibles".

Parasuraman, Berry and Zeithaml (1990) established five service quality dimensions which are: first, "TANGTBLES-physical facilities, equipment, and appearance of personnel". Second, "RESPONSIVENESS- willingness to help customers and provide prompt service". Third, "ASSURANCE- knowledge and courtesy of employees and their ability to convey trust and confidence". Fourth, "EMPATHY-the degree of caring, individualized attention the hotel provides its guests". Finally, "RELIABILITY-the degree to which the promised service is performed dependably and accurately".

The above dimensions proposed "service quality as the gap between customer's expectations (E) and their perception of the service provider's performance $(\mathrm{P})$, hence, the service quality scores (Q) can be measured by subtracting the customer's perception score from the customer's expectations score which can be denoted by the following equation: $\mathrm{Q}=(\mathrm{P}-\mathrm{E})$ ". Many studies of service quality popularly use the SERVQUAL. This model has been designed to be relevant across a broad range of services. SERVQUAL has obliged as the basis for assessing service quality in some contexts, comprising (i.e. "retail apparel specialty stores" (Bishop and Hathcote, 1994), "hospital service" (Jessica et al., 2003).

\section{Research Methods}

An investigative study was administered for this study. After careful review of the literature a closed-ended and self-administered "modified SERVQUAL questionnaire" was designed to examine the gaps between the "expectations and the perceptions" of hotels' borders of Bangladesh. A 5-point Likert scale ranging from 1 for strongly disagree and 5 for strongly agree questionnaire was presented, which comprised three sections. The first section measures the tourists expectations consisting of 22 items regarding SQ in the hotel sectors in Bangladesh by employing the "modified SERVQUAL dimensions". The second section ascertains the tourist' perceptions of SQ whilst the next section relates to the respondents' demographic characteristics. In order to accomplish the objective of this study data were 300 sample sizes were collected from the world's lengthiest sea beach Cox's Bazar and Saint Martin Island which are very famous places in Bangladesh. For determining the sample size, the "rule of thumb is larger than 30 and less than 500' (Roscoe, 1975; Sekaran and Bougie, 2010). Three hundred (300) questionnaires were distributed to the hotels' guests by using a convenience sampling technique. The guests who checked-out from the hotel and about to leave were asked in the survey. Questionnaires were handed to the ones who were ready to fill in the surveys. Data were analysed according to "mean, reliability analysis, independent samples t-tests and single analysis of variance (ANOVA)" via SPSS version 22. A relative analysis between expectations and perceptions based on demographic variables by using "independent samples t-tests and single ANOVA".

\section{Analysis and Findings}

Demographic profile of the respondents

The demographic profile included Gender, age, income level, occupation, marital status, and nationality. According to table 1, the socio- 
Table 1: Demographic characteristics of the respondents

\begin{tabular}{|c|c|c|}
\hline Variables & Frequency & $\%$ \\
\hline \multicolumn{3}{|l|}{ Gender } \\
\hline Male & 228 & 76 \\
\hline Female & 72 & 24 \\
\hline \multicolumn{3}{|l|}{ Age } \\
\hline Up to 25 & 120 & 40 \\
\hline $26-40$ & 117 & 39 \\
\hline $41-55$ & 48 & 16 \\
\hline 56 and above & 15 & 5 \\
\hline \multicolumn{3}{|l|}{ Occupation } \\
\hline Business & 78 & 26 \\
\hline Service holders & 60 & 20 \\
\hline Teacher & 27 & 9 \\
\hline Doctor & 6 & 2 \\
\hline Student & 114 & 38 \\
\hline Government Officers & 12 & 4 \\
\hline Other & 3 & 1 \\
\hline \multicolumn{3}{|l|}{$\begin{array}{l}\text { Respondents Travelling } \\
\text { With }\end{array}$} \\
\hline Family & 123 & 41 \\
\hline Friends & 144 & 48 \\
\hline Colleagues & 33 & 11 \\
\hline \multicolumn{3}{|l|}{ Marital Status } \\
\hline Single & 196 & 65.3 \\
\hline Married & 104 & 34.7 \\
\hline \multicolumn{3}{|l|}{ Education Level } \\
\hline Higher secondary & 75 & 25 \\
\hline Graduate & 114 & 58 \\
\hline Postgraduate & 51 & 17 \\
\hline \multicolumn{3}{|l|}{ Nationality } \\
\hline Bangladeshi & 270 & 90 \\
\hline International & 30 & 10 \\
\hline \multicolumn{3}{|l|}{ Income (Per Month) } \\
\hline Up to TK 30,000 & 156 & 52 \\
\hline TK $31,001-$ TK 50,000 & 60 & 20 \\
\hline TK 50,001 - TK 80,000 & 24 & 8 \\
\hline TK 80,001 and above & 60 & 20 \\
\hline
\end{tabular}

demographic profile of the respondents indicates that $76 \%$ of the respondents are male whilst $24 \%$ are female. This study includes $40 \%$ respondent's age group below 25 years, $39 \%$ respondent's age group 25 to 40 years, $16 \%$ respondent's age was $41^{-}$ 55 years and the smallest age group was 56 and above year's group which represents only $5 \%$. The results also revealed that $58 \%$ of the respondents obtained a bachelor's degree whilst $25 \%$ have higher secondary education and $17 \%$ have postgraduate. The findings also show that the highest number of tourists' (52\%) income level below less than TK 30000 . The lowest income level of the respondents was TK 50001-80000 which represents only 8 percent. From the table, it illustrates that most of the respondents were Bangladeshi and their percentage is 90 . Only 30 respondents were chosen from international, and they represent only 10\%. From the data, it was shown (38\%) respondent's occupation was engaged in studies. The second highest occupation level was business which is 26 percent, 20 percent of the respondents were involved in service holders, and 9 percent of the respondents were a teacher, rest of them are very negligible, and they are doctors, government officers and others which represent 6 , 12 and 3 percent.

\section{$\underline{\text { Reliability analysis }}$}

Reliability is analysed to examine the competence of internal consistency. Reliability refers to the extent to which measurements of the particular test are repeatable (Drost, 2011). Hair, Black, Babin and Anderson (2010) assured that reliability is an "assessment of the degree of uniformity between multiple measurements of variables". The most widespread method of reliability is internal consistency or Cronbach's alpha. It represents the degree of different items that are uniform in evaluating the same underlying construct (Cooper and Schindller, 2006). In this study, Cronbach's alpha was used to test the internal consistency of 22 items for all dimensions, which are: reliability, responsiveness, assurance, empathy, and tangibles. The values of Cronbach's alpha lie between 0 to 1 . It is commonly known that values of 0.70 or higher indicate good reliability (Sekaran and Bougie, 2010).

Table 2: Cronbach's Alpha for individual dimensions

\begin{tabular}{|l|l|l|l|}
\hline Constructs & $\begin{array}{l}\text { Numbe } \\
\text { rof } \\
\text { Items }\end{array}$ & $\begin{array}{l}\text { Cronbach's } \\
\text { Alpha(a) } \\
\text { (Expectations) }\end{array}$ & $\begin{array}{l}\text { Cronbach's } \\
\text { Alpha( } \boldsymbol{( \alpha )} \\
\text { (Perceptions) }\end{array}$ \\
\hline Reliability & 5 & .788 & .854 \\
\hline Responsiveness & 4 & .831 & .866 \\
\hline Assurance & 3 & .780 & .841 \\
\hline Empathy & 5 & .771 & .843 \\
\hline Tangibility & 5 & .786 & .847 \\
\hline
\end{tabular}

From the above table, it shows that all values of Cronbach's alpha exceed 0.70 for all the dimensions. This indicates all the statements in the analysis are reliable. 
Table 3: Mean difference between Customer Expectation and Customer Perception

\begin{tabular}{|c|c|c|c|}
\hline Items & 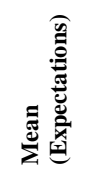 & 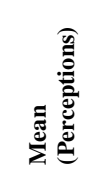 & 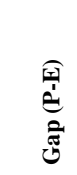 \\
\hline \multicolumn{4}{|l|}{ Reliability } \\
\hline $\begin{array}{l}\text { "When A Smart hotel promises to do } \\
\text { something by a certain time, it should do so. }\end{array}$ & 4.49 & 3.7 & -0.79 \\
\hline $\begin{array}{l}\text { When I have a problem, A Smart hotel should } \\
\text { show a sincere interest in solving it. }\end{array}$ & 4.41 & 3.56 & -0.85 \\
\hline $\begin{array}{l}\text { A Smart Hotel should perform the service } \\
\text { right the first time }\end{array}$ & 4.59 & 3.4567 & -1.133 \\
\hline $\begin{array}{l}\text { A Smart Hotel should provide its services at } \\
\text { the time it promises to do so }\end{array}$ & 4.29 & 3.4567 & -0.833 \\
\hline $\begin{array}{l}\text { A Smart Hotel should keep its record } \\
\text { accurately }\end{array}$ & 4.35 & 3.4867 & -0.863 \\
\hline Average Reliability & 4.426 & 3.532 & -0.894 \\
\hline \multicolumn{4}{|l|}{ Responsiveness } \\
\hline $\begin{array}{l}\text { Employees in a hotel should give me quick } \\
\text { service }\end{array}$ & 4.7 & 3.5933 & -1.107 \\
\hline $\begin{array}{l}\text { Employees in a hotel should be willing to help } \\
\text { me }\end{array}$ & 4.54 & 3.6967 & -0.843 \\
\hline $\begin{array}{l}\text { Employees in a hotel should be never too busy } \\
\text { to respond to my request. }\end{array}$ & 4.41 & 3.73 & -0.68 \\
\hline $\begin{array}{l}\text { Employees in a hotel should inform customers } \\
\text { exactly when services will be performed }\end{array}$ & 4.5 & 3.57 & -0.93 \\
\hline Average Responsiveness & 4.537 & 3.647 & -0.89 \\
\hline \multicolumn{4}{|l|}{ Assurance } \\
\hline $\begin{array}{l}\text { The behavior of employees in A Smart Hotel } \\
\text { should instill confidence in me }\end{array}$ & 4.29 & 3.4667 & -0.823 \\
\hline $\begin{array}{l}\text { I should feel safe in my transactions with a } \\
\text { Hotel }\end{array}$ & 4.67 & 4.04 & -0.63 \\
\hline $\begin{array}{l}\text { Employees in a hotel should be consistently } \\
\text { courteous with me }\end{array}$ & 4.66 & 3.9033 & -0.757 \\
\hline $\begin{array}{l}\text { Employees in a Smart hotel should have the } \\
\text { knowledge to answer my question. }\end{array}$ & 4.69 & 3.82 & -0.87 \\
\hline Average Assurance & 4.577 & 3.807 & -0.769 \\
\hline \multicolumn{4}{|l|}{ Empathy } \\
\hline $\begin{array}{l}\text { A Smart Hotel should give me individual } \\
\text { attention }\end{array}$ & 4.43 & 3.77 & -0.663 \\
\hline $\begin{array}{l}\text { A Smart Hotel should have employees who } \\
\text { should give me individual attention. }\end{array}$ & 4.34 & 3.6767 & -0.667 \\
\hline A Smart Hotel has my best interests at heart. & 4.1333 & 3.5533 & -0.58 \\
\hline $\begin{array}{l}\text { Employees of A Smart Hotel should } \\
\text { understand my specific needs. }\end{array}$ & 4.54 & 3.5767 & -0.963 \\
\hline $\begin{array}{l}\text { Hotels should have convenient operating } \\
\text { business hours. }\end{array}$ & 4.88 & 3.57 & -1.31 \\
\hline Average Empathy & 4.465 & 3.629 & -0.835 \\
\hline \multicolumn{4}{|l|}{ Tangibility } \\
\hline $\begin{array}{l}\text { A Smart Hotel should have modern-looking } \\
\text { equipment }\end{array}$ & 4.69 & 3.8633 & -0.827 \\
\hline $\begin{array}{l}\text { A Smart hotel's physical facilities should be } \\
\text { visually appealing. }\end{array}$ & 4.59 & 3.6067 & -0.983 \\
\hline $\begin{array}{l}\text { Smart hotel's employees should be neat and } \\
\text { clean. }\end{array}$ & 4.88 & 3.7133 & -1.167 \\
\hline $\begin{array}{l}\text { Materials associated with the service (such as } \\
\text { forms, bills, seating arrangement) should be } \\
\text { visually appealing at the hotel". }\end{array}$ & 4.67 & 3.7 & -0.97 \\
\hline Average Tangibility & 4.707 & 3.72 & -0.987 \\
\hline Overall & 4.534 & 3.659 & -0.874 \\
\hline
\end{tabular}

Table 3 exposed that the difference between perception and expectation for all items of service quality was negative. This negative score indicates that tourists' expectation was higher than their perception. It is also revealed that the difference between the average score of expectation and perception is $(-0.894)$. Hence the average score of expectation is 4.426 and an average score of perception is 3.532. Moreover, it shows that a clear gap between the perception and expectation of hotel service quality under the responsiveness dimension where the mean score of expectation and perception are 4.53 and 3.647 respectively and the average gap is -0.89 . Under the assurance dimension, it is seen that there is a gap between customer expectation and customer perception. It reveals that the difference between the mean score of expectation and perception is $(-0.769)$. Hence the mean score of expectation is 4.577 and the mean score of perception is 3.807. Furthermore, it shows that the mean gap between the expectation and perception of hotel services concerning empathy dimension is $(-0.835)$ whilst the mean score of expectation and perception are 4.465 and 3.629. Finally, from the above data, it shows that there is a gap (-0.97) between the expectation and perception of hotel services for the tangibles dimension. Regarding expectation, the highest mean was found 4.88 in the tangibles dimension, and the item is "a smart hotel's employees should be neat and clean," and the lowest mean was found in perception level is 3.46 in the assurance dimension. Considering all five dimensions from the above table, it indicates that the highest gap between expectation and perception was found on tangibles (-0.97) dimension and the lowest gap were found on assurance dimension. The overall mean score of expectation and perception is 4.534 and 3.659 respectively, and the mean gap is -0.874 . 
Table 4: Independent sample $t$ tests

\begin{tabular}{|c|c|c|c|c|c|c|c|}
\hline \multicolumn{8}{|c|}{$\begin{array}{l}\text { Independent sample } t \text { test based on Gender for Customer } \\
\text { Perception }\end{array}$} \\
\hline \multirow[t]{2}{*}{ Items } & \multirow[t]{2}{*}{ Gender } & \multirow[t]{2}{*}{$\mathrm{N}$} & \multirow[t]{2}{*}{ Mean } & \multicolumn{2}{|c|}{$\begin{array}{c}\text { Equality of Variances } \\
\text { ( Levene's Test) }\end{array}$} & \multicolumn{2}{|c|}{ Perception } \\
\hline & & & & F value & Significant & $t$ value & Significance \\
\hline \multirow{2}{*}{ Reliability } & Male & 228 & 3.5605 & \multirow{2}{*}{1.785} & \multirow{2}{*}{.183} & 1.637 & .103 \\
\hline & Female & 72 & 3.4417 & & & 1.712 & .089 \\
\hline \multirow{2}{*}{ Responsiveness } & Male & 228 & 3.6930 & \multirow{2}{*}{2.717} & \multirow{2}{*}{.100} & 2.824 & .005 \\
\hline & Female & 72 & 3.5035 & & & 2.564 & .012 \\
\hline \multirow{2}{*}{ Assurance } & Male & 228 & 3.8476 & \multirow{2}{*}{4.906} & \multirow{2}{*}{.028} & 2.409 & .017 \\
\hline & Female & 72 & 3.6806 & & & 2.182 & .031 \\
\hline \multirow{2}{*}{ Empathy } & Male & 228 & 3.7281 & \multirow{2}{*}{11.834} & \multirow{2}{*}{.001} & 5.487 & .000 \\
\hline & Female & 72 & 3.3167 & & & 4.779 & .000 \\
\hline \multirow{2}{*}{ Tangibles } & Male & 228 & 3.7193 & \multirow[t]{2}{*}{7.139} & \multirow{2}{*}{.008} & -.074 & .941 \\
\hline & Female & 72 & 3.7257 & & & -.066 & .947 \\
\hline
\end{tabular}
Expectation

\begin{tabular}{|c|c|c|c|c|c|c|c|}
\hline \multirow{2}{*}{ Items } & \multirow{2}{*}{ Gender } & \multirow{2}{*}{$\mathbf{N}$} & \multirow{2}{*}{ Mean } & \multicolumn{2}{|c|}{\begin{tabular}{|c|}
$\begin{array}{c}\text { Equality of Variances } \\
\text { ( Levene's Test) }\end{array}$ \\
\end{tabular}} & \multicolumn{2}{|c|}{ Expectation } \\
\hline & & & & $F$ value & Significant & $\begin{array}{c}\text { T } \\
\text { value }\end{array}$ & Significanc \\
\hline \multirow{2}{*}{ Reliability } & Male & 228 & 4.4763 & \multirow{2}{*}{10.672} & \multirow{2}{*}{.001} & 3.820 & .000 \\
\hline & Female & 72 & 4.2667 & & & 3.359 & .001 \\
\hline \multirow{2}{*}{ Responsiveness } & Male & 228 & 4.5680 & \multirow{2}{*}{3.758} & \multirow{2}{*}{.053} & 2.979 & .003 \\
\hline & Female & 72 & 4.4410 & & & 2.673 & .009 \\
\hline \multirow{2}{*}{ Assurance } & Male & 228 & 4.6075 & \multirow{2}{*}{7.997} & \multirow{2}{*}{.005} & 2.547 & .011 \\
\hline & Female & 72 & 4.4826 & & & 2.411 & .018 \\
\hline \multirow{2}{*}{ Empathy } & Male & 228 & 4.5526 & \multirow{2}{*}{5.491} & \multirow{2}{*}{.020} & 7.105 & .000 \\
\hline & Female & 72 & 4.1917 & & & 6.269 & .000 \\
\hline \multirow{2}{*}{ Tangibles } & Male & 228 & 4.7083 & \multirow{2}{*}{3.373} & \multirow{2}{*}{.067} & .068 & .946 \\
\hline & Female & 72 & 4.7049 & & & .064 & .949 \\
\hline
\end{tabular}

Average $\quad$ Male $=4.58$, Female $=4.42$

Independent sample t-test based on Nationality for Customer

\begin{tabular}{|c|c|c|c|c|c|c|c|}
\hline \multicolumn{8}{|c|}{ Expectation } \\
\hline \multirow[t]{2}{*}{ Items } & \multirow[t]{2}{*}{ Nationality } & \multirow[t]{2}{*}{$\mathbf{N}$} & \multirow[t]{2}{*}{ Mean } & \multicolumn{2}{|c|}{$\begin{array}{c}\text { Equality of } \\
\text { Variances } \\
\text { ( Levene's Test) }\end{array}$} & \multicolumn{2}{|c|}{ Expectation } \\
\hline & & & & F- value & Significan & $\begin{array}{c}T- \\
\text { value }\end{array}$ & Significance \\
\hline \multirow{2}{*}{ Reliability } & Bangladeshi & 270 & 4.3822 & \multirow{2}{*}{\begin{tabular}{l|l}
2 & 36.074 \\
0 &
\end{tabular}} & \multirow{2}{*}{.000} & \begin{tabular}{|c|}
- \\
5.768
\end{tabular} & .000 \\
\hline & International & 30 & 4.8200 & & & \begin{tabular}{|c|}
- \\
9.118
\end{tabular} & .000 \\
\hline \multirow{2}{*}{ Responsiveness } & Bangladeshi & 270 & 4.5287 & \multirow{2}{*}{6.969} & \multirow{2}{*}{.009} & $\left|\begin{array}{c}- \\
1.433\end{array}\right|$ & .153 \\
\hline & International & 30 & 4.6167 & & & \begin{tabular}{|c|}
- \\
2.074 \\
\end{tabular} & .044 \\
\hline \multirow{2}{*}{ Assurance } & Bangladeshi & 270 & 4.5583 & \multirow{2}{*}{16.615} & \multirow{2}{*}{.000} & \begin{tabular}{|c|}
- \\
2.752 \\
\end{tabular} & .006 \\
\hline & International & 30 & 4.7500 & & & $\begin{array}{c}- \\
3.927\end{array}$ & .000 \\
\hline \multirow{2}{*}{ Empathy } & Bangladeshi & 270 & 4.4622 & \multirow{2}{*}{5.106} & \multirow{2}{*}{.025} & -.483 & .629 \\
\hline & International & 30 & 4.5000 & & & -.650 & .519 \\
\hline \multirow{2}{*}{ Tangibles } & Bangladeshi & 270 & 4.6843 & \multirow{2}{*}{22.781} & \multirow{2}{*}{.000} & $\begin{array}{c}- \\
3.273 \\
\end{array}$ & .001 \\
\hline & International & 30 & 4.9167 & & & $\begin{array}{c}- \\
6.784\end{array} \mid$ & .000 \\
\hline
\end{tabular}

Source: Authors Computation
Md. Alauddin, et al.

Table 5: Independent sample t-test based on Nationality for Customer Perception

\begin{tabular}{|c|c|c|c|c|c|c|c|}
\hline \multirow[t]{2}{*}{ Items } & \multirow[t]{2}{*}{ Nationality } & & \multirow[t]{2}{*}{ Mean } & \multicolumn{2}{|c|}{\begin{tabular}{|l|} 
Equality of \\
Variances ( \\
Levene's Test) \\
\end{tabular}} & \multicolumn{2}{|c|}{ Perception } \\
\hline & & & & F value & Significant & $\left.t\right|_{\text {value }} ^{t}$ & Significance \\
\hline \multirow{2}{*}{ Reliability } & Bangladeshi & i 270 & 3.5452 & \multirow{2}{*}{28.885} & \multirow{2}{*}{.000} & .204 & .103 \\
\hline & International & & 3.4133 & & & .002 & .089 \\
\hline \multirow{2}{*}{ Responsivenes } & Bangladeshi & 270 & 3.6861 & \multirow{2}{*}{14.461} & \multirow{2}{*}{.000} & .000 & .005 \\
\hline & International & & 3.3000 & & & .000 & .012 \\
\hline \multirow{2}{*}{ Assurance } & Bangladeshi & $\mathrm{i} 270$ & 3.8611 & \multirow{2}{*}{15.955} & \multirow{2}{*}{.000} & .000 & .017 \\
\hline & International & & 3.3250 & & & .000 & .031 \\
\hline \multirow{2}{*}{ Empathy } & Bangladeshi & i 270 & 3.6089 & \multirow{2}{*}{12.450} & \multirow{2}{*}{.000} & .067 & .000 \\
\hline & International & & 3.8133 & & & .001 & .000 \\
\hline \multirow{2}{*}{ Tangibles } & Bangladeshi & i 270 & 3.7583 & \multirow{2}{*}{5.340} & \multirow{2}{*}{.022} & .002 & .941 \\
\hline & International & & 3.3833 & & & & .947 \\
\hline Average & Bangladeshi & $i=3.69$ & 9, Intern & ational $=3$ & 3.44 & & \\
\hline
\end{tabular}

Source: Authors Computation

Table 6: One -way ANOVA tests based on Age groups

\begin{tabular}{|c|c|c|c|c|c|c|c|c|}
\hline \multirow[b]{2}{*}{ Items } & \multirow[b]{2}{*}{ Age Group } & \multirow[b]{2}{*}{$\mathbf{N}$} & \multirow[b]{2}{*}{ Mean } & \multicolumn{2}{|c|}{ Expectation } & \multirow[b]{2}{*}{ Mean } & \multicolumn{2}{|c|}{ Perception } \\
\hline & & & & $\begin{array}{l}\text { F- } \\
\text { value }\end{array}$ & $\begin{array}{l}\text { P- } \\
\text { Value }\end{array}$ & & $\begin{array}{l}\text { F - } \\
\text { value }\end{array}$ & $\begin{array}{l}\text { P - } \\
\text { Value }\end{array}$ \\
\hline \multirow{4}{*}{ Reliability } & Below 25 & 120 & 4.2650 & \multirow{4}{*}{14.501} & \multirow{4}{*}{.000} & 3.3383 & \multirow{4}{*}{13.541} & \multirow{4}{*}{1.000} \\
\hline & $26-40$ & 117 & 4.4718 & & & 3.6205 & & \\
\hline & $41-55$ & 48 & 4.6750 & & & 3.8458 & & \\
\hline & 56> & 15 & 4.5600 & & & 3.3867 & & \\
\hline \multirow{4}{*}{ Responsiveness } & Below 25 & 120 & 4.4938 & \multirow{4}{*}{81.518} & \multirow{4}{*}{.210} & 3.6604 & \multirow{4}{*}{.349} & \multirow{4}{*}{.790} \\
\hline & $26-40$ & 117 & 4.5513 & & & 3.6154 & & \\
\hline & $41-55$ & 48 & 4.5938 & & & 3.6979 & & \\
\hline & 56> & 15 & 4.6000 & & & 3.6333 & & \\
\hline \multirow{4}{*}{ Assurance } & Below 25 & 120 & 4.5063 & \multirow{4}{*}{-6.898} & \multirow{4}{*}{.035} & 3.7896 & \multirow{4}{*}{.654} & \multirow{4}{*}{.581} \\
\hline & $26-40$ & 117 & 4.6090 & & & 3.8419 & & \\
\hline & $41-55$ & 48 & 4.6406 & & & 3.7396 & & \\
\hline & 56> & 15 & 4.7000 & & & 3.9000 & & \\
\hline \multirow{4}{*}{ Empathy } & Below 25 & 120 & 4.3833 & \multirow{4}{*}{-3.154} & \multirow{4}{*}{.025} & 3.4817 & \multirow{4}{*}{4.965} & \multirow{4}{*}{.002} \\
\hline & $26-40$ & 117 & 4.5060 & & & 3.6991 & & \\
\hline & $41-55$ & 48 & 4.5292 & & & 3.8125 & & \\
\hline & 56> & 15 & 4.6133 & & & 3.6800 & & \\
\hline \multirow{4}{*}{ Tangibles } & Below 25 & 120 & 4.6813 & \multirow{4}{*}{2.471} & \multirow{4}{*}{.062} & 3.6479 & \multirow{4}{*}{-1.393} & \multirow{4}{*}{.245} \\
\hline & $26-40$ & 117 & 4.6923 & & & 3.7585 & & \\
\hline & $41-55$ & 48 & 4.7344 & & & 3.8438 & & \\
\hline & 56> & 15 & 4.9500 & & & 3.6167 & & \\
\hline
\end{tabular}

Source: Authors Computation 
Table 7: One -way ANOVA tests based on educational background

\begin{tabular}{|c|c|c|c|c|c|c|c|c|}
\hline \multirow[b]{3}{*}{ Items } & \multirow{3}{*}{$\begin{array}{l}\text { Education } \\
\text { Levels }\end{array}$} & \multirow[b]{3}{*}{$\mathbf{N}$} & \multirow[b]{3}{*}{ Mean } & \multirow{2}{*}{\multicolumn{2}{|c|}{ Expectation }} & \multirow[b]{3}{*}{ Mean } & \multirow{2}{*}{\multicolumn{2}{|c|}{ Perception }} \\
\hline & & & & & & & & \\
\hline & & & & \begin{tabular}{|c|}
$\mathbf{F}$ \\
value
\end{tabular} & Sig. & & \begin{tabular}{c|}
$\mathbf{F}$ \\
value
\end{tabular} & $\begin{array}{c}\text { Signific } \\
\text { ance }\end{array}$ \\
\hline \multirow{3}{*}{ Reliability } & $\begin{array}{l}\text { Higher } \\
\text { secondary }\end{array}$ & 120 & 4.2080 & \multirow{3}{*}{19.514} & \multirow{3}{*}{.000} & 3.5013 & \multirow{3}{*}{3.107} & \multirow{3}{*}{.046} \\
\hline & Graduate & 117 & 4.4586 & & & 3.4954 & & \\
\hline & Postgraduate & 48 & 4.6353 & & & 3.7020 & & \\
\hline \multirow{3}{*}{$\begin{array}{l}\text { Responsive } \\
\text { ness }\end{array}$} & $\begin{array}{l}\text { Higher } \\
\text { secondary }\end{array}$ & 75 & 4.4500 & \multirow{3}{*}{4.292} & \multirow{3}{*}{.015} & 3.5833 & \multirow{3}{*}{.951} & \multirow{3}{*}{.388} \\
\hline & Graduate & 174 & 4.5776 & & & 3.6595 & & \\
\hline & Postgraduate & 51 & 4.5294 & & & 3.7010 & & \\
\hline \multirow{3}{*}{ Assurance } & \begin{tabular}{|l|} 
Higher \\
secondary
\end{tabular} & 75 & 4.3600 & \multirow{3}{*}{22.570} & \multirow{3}{*}{.000} & 3.6467 & \multirow{3}{*}{5.472} & \multirow{3}{*}{.005} \\
\hline & Graduate & 174 & 4.6767 & & & 3.8793 & & \\
\hline & Postgraduate & 51 & 4.5588 & & & 3.7990 & & \\
\hline \multirow{3}{*}{ Empathy } & $\begin{array}{l}\text { Higher } \\
\text { secondary }\end{array}$ & 75 & 4.3013 & \multirow{3}{*}{9.256} & \multirow{3}{*}{.000} & 3.4240 & \multirow{3}{*}{7.420} & \multirow{3}{*}{.001} \\
\hline & Graduate & 174 & 4.5057 & & & 3.6701 & & \\
\hline & Postgraduate & 51 & 4.5725 & & & 3.7922 & & \\
\hline \multirow{3}{*}{ Tangibles } & $\begin{array}{l}\begin{array}{l}\text { Higher } \\
\text { secondary }\end{array} \\
\end{array}$ & 75 & 4.5000 & \multirow{3}{*}{17.041} & \multirow{3}{*}{.000} & 3.5033 & \multirow{3}{*}{6.216} & \multirow{3}{*}{.002} \\
\hline & Graduate & 174 & 4.7716 & & & 3.8075 & & \\
\hline & Postgraduate & 51 & 4.7941 & & & 3.7451 & & \\
\hline
\end{tabular}

Source: Authors Computation

Independent sample t-test on hotel service quality This test was used to pinpoint the comparison between customer expectation and perceptions on service quality of hotel sectors in Bangladesh based on gender and nationality (see Table 4 and Table 5). According to the result of this test, there is very little meaningful difference between males and females. The low mean difference is also observed between Bangladeshi and international tourists. However, in both cases, only the service qualities dimension 'tangibles' is not a significant difference according to gender. However, table 5 clarifies that three-dimension are significant differences between Bangladeshi and international respondents, namely, reliability, assurance, and tangibles in expectation levels. Which measures that international tourists have more expectation on reliability $(\mu=4.8200)$, assurance $(\mu=4.7500)$, and tangibles $(\mu=4.9167)$, compared to Bangladeshi tourists. Similarly, both Bangladeshi and international respondents have significant differences in service quality perceptions, namely, responsiveness, assurance, and empathy. $\mathrm{P}$ values of Leven's test for equality of variances in case of independent sample t-test (see Table 4 and Table 5) are lower than 0.05 except in reliability. Thus, it tin be concluded that there is a significant difference in the service quality gap between expectation and perceptions regarding the responsiveness, assurance, empathy and tangibility dimension. ANOVA test on age, education, and occupation single ANOVA test have also been applied to three different age groups
Table 8: One -way ANOVA tests based on occupation

\begin{tabular}{|c|c|c|c|c|c|c|c|c|}
\hline \multirow[b]{2}{*}{ Items } & \multirow[b]{2}{*}{ 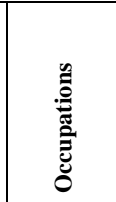 } & \multirow[b]{2}{*}{$\mathbf{N}$} & \multirow[b]{2}{*}{ Mean } & \multicolumn{2}{|c|}{ Expectation } & \multirow[b]{2}{*}{ Mean } & \multicolumn{2}{|c|}{ Perception } \\
\hline & & & & 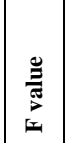 & 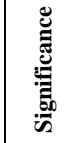 & & 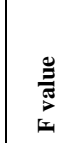 & 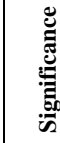 \\
\hline \multirow{7}{*}{ 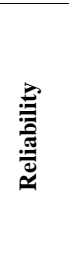 } & Business & 78 & 4.4846 & \multirow{7}{*}{$4^{10.22}$} & \multirow{7}{*}{.000} & 3.8026 & \multirow{7}{*}{9.016} & \multirow{7}{*}{.000} \\
\hline & $\begin{array}{l}\text { Service } \\
\text { holders }\end{array}$ & 60 & 4.6700 & & & 3.5800 & & \\
\hline & Teacher & 27 & 4.4667 & & & 3.4889 & & \\
\hline & Doctor & 6 & 3.9000 & & & \begin{tabular}{|l|}
2.6667 \\
\end{tabular} & & \\
\hline & Student & 114 & 4.2737 & & & 3.3684 & & \\
\hline & $\begin{array}{l}\text { Governme } \\
\text { nt officer }\end{array}$ & 12 & 4.5500 & & & 3.6000 & & \\
\hline & Others & 3 & 4.0000 & & & 3.6000 & & \\
\hline \multirow{7}{*}{ 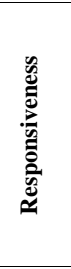 } & Business & 78 & 4.6250 & \multirow{7}{*}{4.739} & \multirow{7}{*}{.000} & 3.6955 & \multirow{7}{*}{2.441} & \multirow{7}{*}{.026} \\
\hline & $\begin{array}{l}\text { Service } \\
\text { holders }\end{array}$ & 60 & 4.6125 & & & 3.5875 & & \\
\hline & Teacher & 27 & 4.5278 & & & 3.7500 & & \\
\hline & Doctor & 6 & 4.1250 & & & 3.0417 & & \\
\hline & Student & 114 & 4.4803 & & & 3.6338 & & \\
\hline & \begin{tabular}{|l} 
Governme \\
nt officer
\end{tabular} & 12 & 4.4375 & & & 3.8750 & & \\
\hline & Others & 3 & 4.2500 & & & 3.5000 & & \\
\hline \multirow{7}{*}{ 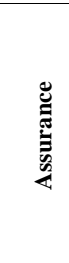 } & Business & 78 & 4.5865 & \multirow{7}{*}{2.597} & \multirow{7}{*}{.018} & 3.8333 & \multirow{7}{*}{4.819} & \multirow{7}{*}{.000} \\
\hline & $\begin{array}{l}\text { Service } \\
\text { holders }\end{array}$ & 60 & 4.6125 & & & 3.7500 & & \\
\hline & Teacher & 27 & 4.6944 & & & 4.0000 & & \\
\hline & Doctor & 6 & 4.3750 & & & 3.3333 & & \\
\hline & Student & 114 & 4.5066 & & & 3.7346 & & \\
\hline & $\begin{array}{l}\text { Governme } \\
\text { nt officer }\end{array}$ & 12 & 4.8125 & & & 4.3750 & & \\
\hline & Others & 3 & 4.7500 & & & 4.0000 & & \\
\hline \multirow{7}{*}{ 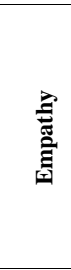 } & Business & 78 & 4.4769 & \multirow{7}{*}{4.768} & \multirow{7}{*}{.000} & 3.8128 & \multirow{7}{*}{3.750} & \\
\hline & $\begin{array}{l}\text { Service } \\
\text { holders }\end{array}$ & 60 & 4.5533 & & & 3.6800 & & \\
\hline & Teacher & 27 & 4.6444 & & & 3.5407 & & \\
\hline & Doctor & 6 & 3.9333 & & & 2.9333 & & .001 \\
\hline & Student & 114 & 4.3860 & & & 3.5298 & & \\
\hline & $\begin{array}{l}\text { Governme } \\
\text { nt officer }\end{array}$ & 12 & 4.6500 & & & 3.7167 & & \\
\hline & Others & 3 & 4.2000 & & & 3.4667 & & \\
\hline & Business & 78 & 4.6827 & & & 3.9551 & & \\
\hline & $\begin{array}{l}\text { Service } \\
\text { holders }\end{array}$ & 60 & 4.7750 & & & 3.6042 & & \\
\hline & Teacher & 27 & 4.8889 & & & 3.8611 & & \\
\hline 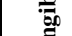 & Doctor & 6 & 4.6250 & 2.823 . & .011 & 2.9167 & 5.884 & .000 \\
\hline స్ & Student & 114 & 4.6316 & & & 3.6009 & & \\
\hline & $\begin{array}{l}\text { Governme } \\
\text { nt officer }\end{array}$ & 12 & 4.8125 & & & 3.8125 & & \\
\hline & Others & 3 & 5.0000 & & & 4.5000 & & \\
\hline
\end{tabular}

Source: Authors Computation

namely, age, education, and occupation. The results from single ANOVA test on age groups observed that there is a significant difference in reliability and empathy except for responsiveness, assurance, and tangibility. In the case of education, it shows that there is a significant difference in reliability, assurance, empathy, and tangibility except for responsiveness. It was also observed from one -way ANOVA tests of occupation that there is a significant difference between customer expectation and perception of all service quality dimensions. However, the internal mean difference (see Table 6, Table 7 and Table 8) is also observed among age category, education level, and occupation level. 
ANOVA test on age, education, and occupation One-way ANOVA test has also been applied to three different age groups namely, age, education and occupation. The results from one--way ANOVA test on age groups observed that there is a significant difference in reliability and empathy except for responsiveness, assurance, and tangibility. In the case of education, it shows that there is a significant difference in reliability, assurance, empathy, and tangibility except for responsiveness. It was also observed from one-way ANOVA tests of occupation that there is a significant difference between customer expectation and perception of all service quality dimensions. However, the internal mean difference (see Table 6, Table 7 and Table 8) is also observed among age category, education level, and occupation level.

\section{Conclusion and Recommendations}

Identifying customer need is the prerequisite to serving the customers in a proper way that can help industry professionals. Today, firms are facing different challenges from different sides which should be overcome by developing the quality of service. This is the best way for service entrepreneurs to enhance quality. Therefore, it is very important for every company to assess the service quality dimensions. After assessing they will be able to realize the importance of these dimensions. It should be kept in mind that organizations cannot achieve their target without an appropriate quality of service. From the gap analysis, it is observed that there is a gap between customer perception and customer expectation of hotel service quality in all dimensions. That means customers are not getting their expected service from the hotels. Considering all five dimensions from the above table- 1 , it indicates that the highest gap between expectation and perception was found on tangibles (-0.97) dimension and the lowest gap was found on assurance dimension. The hotel managers should adopt a new strategy to reduce this gap for tangibles dimensions. It tin be done by designing the hotels properly. The physical facilities of hotels should be visually appealing to the tourists. Employees of the hotel should be neat and clean. From the independent sample t-test based on gender and nationality, it is observed that there does not exist any significant difference intangibles dimension and most of the dimensions have found a significant difference. The findings show that consumer's expectations are higher than the level of perception of hotel services in Bangladesh. To reduce this gap, service organizations should have integrated planning for providing efficient services to their clients. They need to identify the weakness of different dimensions of hotel service quality. To be succeeded in any organization, they need to emphasis on the service quality as one of their strategies (i.e. giving customers what they want) (Mey et al., 2006). Moreover, training is provided among employees (Kessler, 1996). As a whole, once customers' requirements are identified and understood, hotel managers are more likely to be able to anticipate and fulfill their customers' needs and wants, rather than merely reacting to their dissatisfaction (Juwaheer and Ross, 2003). Hoffman and Bateson (2001) recommended that employees must be careful and willing to serve their clients politely. In designing this study, there are some limitations, but some still need to be addressed. Firstly, the study has been accompanied only by hotels in cox's Bazar and Saint Martin, Bangladesh. Future researches should go to examine the service industry by taking a sample from other cities in Bangladesh. Besides, this study centred only on the service quality perspective of hotels (Akan, 1995).

\section{References}

Akan, P. (1995), "Dimensions of service quality: A study in Istanbul", Managing Service Quality: An International Journal, Vol. 5, No. 6, pp.39-43. https://doi.org/10.1108/09604529510796575

Barsky, J.D. (1992), "Customer satisfaction in the hotel industry: Meaning and measurement", Hospitality Research Journal, Vol. 16, No. 1, pp.51-73.

https://doi.org/10.1177/109634809201600105

Barsky, J.D. and Labagh, R. (1992), "A strategy for customer satisfaction", Cornell Hotel and Restaurant", Administration Quarterly, Vol. 33, No 5 , pp. $32-40$ https://doi.org/10.1177/001088049203300524

Bishop Gagliano, K. and Hathcote, J. (1994), "Customer Expectations and Perceptions of Service Quality in Retail Apparel Specialty Stores", Journal of Services Marketing, Vol. 8, No. 1, pp.60-69. https://doi.org/10.1108/08876049410053311

Bojanic, D.C. and Drew Rosen, L. (1994), "Measuring service quality in restaurants: An application of the SERVQUAL instrument", Hospitality Research Journal, Vol. 18, No. 1, pp.3-14. https://doi.org/10.1177/109634809401800102

Buttle, F. (1995), SERVQUAL: Review, critique, research agenda. European Journal of Marketing, Vol. 30, No. 1, pp 8-32. https://doi.org/10.1108/03090569610105762

Cooper, D.R. and Schindler, P.S. (2006), Marketing research. New York, NY: McGraw-Hill/Irwin. 
Devi Juwaheer, T. (2004), "Exploring international tourists' perceptions of hotel operations by using a modified SERVQUAL approach - a case study of Mauritius", Managing Service Quality: An International Journal, Vol. 14, No. 5, pp.350-364. https://doi.org/10.1108/09604520410557967

Devi Juwaheer, T. and Lee Ross, D. (2003), "A study of hotel guest perceptions in Mauritius", International Journal of Contemporary Hospitality Management, Vol. 15, No. 2, pp.105115. https://doi.org/10.1108/09596110310462959

Donnelly, M., Neil, J., Rimmer, R. and Shiu, M. (2006), "Assessing the quality of police service using SERVQUAL". An International Journal of Police Strategies \& Management, Vol. 29, No. 1, pp.92105. https://doi.org/10.1108/13639510610648502

Drost, E.A. (2011), "Validity and reliability in social science research", Education Research and perspectives, Vol. 38, No. 1, pp.105.

Edvardsson, B. and Olsson, J. (1996), "Key concepts for new service development", Service Industries Journal, Vol. 16, No. 2, pp.140-164. https://doi.org/10.1080/02642069600000019

Ekinci, Y., Prokopaki, P. and Cobanoglu, C. (2003), "Service quality in Cretan accommodations: marketing strategies for the UK holiday market", International Journal of Hospitality Management, Vol. 22, No. 1, pp.47-66. https://doi.org/10.1016/S0278-4319(02)00072-5

Getty, J.M. and Thompson, K.N. (1994), "A procedure for scaling perceptions of lodging quality", Hospitality Research Journal, Vol. 18, No. 2, pp.75-96.

https://doi.org/10.1177/109634809401800206

Hair Jr., J.F., Black, W.C., Babin, B.J. and Anderson, R.E. (2010), Multivariate Data Analysis A Global Perspective. Upper Saddle River, NJ: Pearson Education.

Hassan, A., Parvez, M. and Ekiz, E. (2019), Technology Induced Loyalty Schemes for Customer Relationship Management and Positive Purchase Decisions. Paper presented at The $9^{\text {th }}$ Advances in Hospitality and Tourism Marketing and Management (AHTMM) Conference. Portsmouth: University of Portsmouth and the Washington State University. The $09^{\text {th }}-12^{\text {th }}$ July, 2019.

Hoffman, K.D. and Bateson, J.E. (2001), Essentials of services marketing: Concepts, strategies and cases. London: Cengage Learning.

Jeong, M. and Oh, H. (1998), "Quality function deployment: An extended framework for service quality and customer satisfaction in the hospitality industry" International Journal of Hospitality Management, Vol. 17, No. 4, pp.375390. https://doi.org/10.1016/S0278-
Jessica Hwang, L.J., Eves, A. and Desombre, T. (2003), "Gap analysis of patient meal service perceptions", International Journal of Health Care Quality Assurance, Vol. 16, No. 3, pp.143153. https://doi.org/10.1108/09526860310470874

Kessler, S. (1996), Measuring and managing customer satisfaction: Going for the gold. Milwaukee, WI: ASQ Quality Press.

Knutson, B., Stevens, P., Patton, M. and Thompson, C. (1993), "Consumers' expectations for service quality in economy, mid-price and luxury hotels", Journal of Hospitality \& Leisure Marketing, Vol. 1, No. 2, pp.27-43. https://doi.org/10.1300/J150v01n02_03

Kotler, P. and Gertner, D. (2002), "Country as brand, product, and beyond: A place marketing and brand management perspective", Journal of brand management, Vo. 9, N0. 4, pp.249-261. https://doi.org/10.1057/palgrave.bm.2540076

Kotler, P. and Keller, K.L. (2009), Marketing management. Upper Saddle River, NJ: Pearson Education.

Lewis, R. C. and Chambers, R. E. (2000), Marketing leadership in hospitality, foundations and practices. New York, NY: Wiley.

Lewis, R. C. and Booms, B. H. (1983), The marketing aspect of service quality. In L. Berry, G. Shostack and G. Upah (eds.), Emerging Perspective on Service Marketing. Chicago, IL: American Marketing Association, pp. 99- 107.

Mazumder, S. and Hasan, A.B.M.R. (2014), "Measuring service quality and customer satisfaction of the hotels in Bangladesh: a study on national and international hotel guest", Journal of Tourism and Hospitality Management, Vol. 2, No. 1, pp.95111.

Mei, A., Dean, A.M. and White, C.J. (1999), "Analysing service quality in the hospitality industry" Managing Service Quality: An International Journal, Vol. 8, No. 2, pp.136-143. https://doi.org/10.1108/09604529910257920

Mey, L.P., Akbar, A.K. and Fie, D.Y.G. (2006), "Measuring service quality and customer satisfaction of the hotels in Malaysia: Malaysian, Asian and non-Asian hotel guests", Journal of Hospitality and Tourism Management, Vol. 13, No. 2, pp.144-160. https://doi.org/10.1375/jhtm.13.2.144

Oberoi, U. and Hales, C. (1990), "Assessing the quality of the conference hotel service product: Towards an empirically based model", Service Industries Journal, Vol.10, N0.4, pp.700-721. https://doi.org/10.1080/02642069000000083

Parasuraman, A., Berry, L.L. and Zeithaml, V.A. (1990), "Guidelines for Conducting Service Quality 
Research", Marketing Research, Vol. 2, No. 4, pp.34-44.

Parasuraman, A., Zeithaml, V. A. and Berry, L. L. (1988), "Servqual: A multiple-item scale for measuring consumer perceptions of service quality", Journal of Retailing, Vol.64, No.1, pp.1240 .

Parasuraman, A., Zeithaml, V.A. and Berry, L.L. (1985), "A conceptual model of service quality and its implications for future research". The Journal of Marketing, Vol. 49, No. 4, pp.41-50. https://doi.org/10.1177/002224298504900403

Patton, R.J., Chen, J. and Siew, T.M. (1994), "Fault diagnosis in nonlinear dynamic systems via neural networks", In 1994 International Conference on Control - Control '94. Coventry: the $21^{\text {st- } 24^{\text {th }} \text { March, } 1994 .}$

Rao, C. P. and Singhapakdi, A. (1997), "Marketing ethics: A comparison between services and other marketing professionals" Journal of Services Marketing, Vol. 11, pp.409-426. doi.org/10.1108/08876049710187509

Roscoe, J.T. (1975), Fundamental research statistics for the behavioral. London: CBLS.

Saleh, F. and Ryan, C. (1991), "Analysing service quality in the hospitality industry using the SERVQUAL model" Service Industries Journal, Vol.11, No. 13, pp.324-345.

https://doi.org/10.1080/02642069100000049

Saleh, F. and Ryan, C. (1992), "Client perceptions of hotels: A multi-attribute approach" Tourism Management, Vol. 13, No, 2, pp.163-168. https://doi.org/10.1016/0261-5177(92)90058-F

Sekaran, U. and Bougie, R. (2010), "Theoretical framework in theoretical framework and hypothesis development". Research methods for business: A skill building approach. Chichester: John Wiley \& Sons.

Seth, N., Deshmukh, S. G. and Vrat, P. (2005), "Service quality models: A review" International Journal of Quality and Reliability Management, Vol. 22, pp.913-949.

https://doi.org/10.1108/02656710510625211

Solomon, M.R. (2009), "Marketing: Real people, real decisions". Upper Saddle River, NJ: Pearson Education.

Tsang, N. and Qu, H. (2000), "Service quality in China's hotel industry: A perspective from tourists and hotel managers", International Journal of Contemporary Hospitality Management, Vol. 12, No. 5, pp.316-326. https://doi.org/10.1108/09596110010339706

Webster, C. and Hung, L.C. (1994), "Measuring Service Quality and Promoting Decentring" The TQM Magazine, 6(5), pp.50-55.
Wong Ooi Mei, A., Dean, A.M. and White, C.J. (1999), "Analysing service quality in the hospitality industry", Managing Service Quality: An International Journal, Vol. 9, No. 2, pp.136-143. https://doi.org/10.1108/09604529910257920

Zaibaf, M., Taherikia, F. and Fakharian, F. (2013), "Effect of Perceived Service Quality on Customer Satisfaction in Hospitality Industry: Gronroos' Service Quality Model Development" Journal of Hospitality Marketing \& Management, Vol.22, No. 5, pp.490-504. 